\title{
Rui e a Questão Social *.
}

\author{
Alfredo Buzaid \\ Catedrático de Direito Processual Civil na \\ Faculdade de Direito da Universidade do \\ São Paulo.
}

\section{I}

\section{Considerações Gerais.}

SUMÁrio: 1. Livro mau, não, porém, inútil. 2. Retrato ou caricatura? 3. Apreciação geral do capítulo relativo à questão social. 4. Estudo em particular de cada proposição.

1. Um livro mau nem sempre é um livro inútil. E mau o livro que instila veneno de idéias. É mau o livro que deturpa a verdade, prega o ódio e engana o leitor. mau o livro que, a pretexto de fazer literatura, se enreda em tramas políticas, que visam a destruir os valores permanentes da tradição cultural e religiosa de um povo.

Mas, um livro, de mau que é, pode chegar até a ser útil, se tem o condão de despertar a consciência dos intelectuais que, compreendendo o objetivo a que êle se propõe, entram para a luta, sem receios nem esmorecimentos, denunciando o plano, reagindo contra a insídia e castigando o escritor ${ }^{1}$.

* Conferência proferida a 2 de setembro de 1965 na Faculdade de Direito da Universidade de São Paulo, acêrca do capítulo "Rui e a Questão Social", do livro de R. MAGAlHÃes JÚNiOR, intitulado Rui - O Homem e o Mito.

1. Ao escrever "nota à segunda edição", diz Magalhães JúnioR que o livro produziu uma espécie de choque, sendo comentado em páginas inteiras de jornais, em debates da Academia Brasileira de Letras, em colunas literárias e programas de rádio e televisão. Acrescenta que contava com tôdas essas reações, inclusive as da estupidez e má fé. E conclui que o silêncio é que poderia ter sido mortal para 
Magalhães Júnior deu à luz um livro mau; não, porém, inútil. Escreveu-o, a se crer nas datas que figuram no prólogo, entre março de 1962 e março de 1964, justamente no período em que os agitadores buscavam aniqüilar a estrutura social e política do país; e fê-lo mui de harmonia com a tática subversiva, intentando desvanecer, na alma da juventude, a confiança em Rur Barbosa, que a história consagrou como baluarte das liberdades públicas e defensor vitalício das instituições democráticas. Fôrça era, portanto, escachar o homem que as representou num apostolado de meio século, ao longo do qual surpreendeu a vocação cristã da nacionalidade, ajudou a fundar a República e consolidou o Estado brasileiro na exegese construtiva de sua Lei fundamental.

2. A leitura do livro de Magalhães Júnior convencenos fàcilmente que o seu objetivo não foi o de proceder a uma revisão de Ruı, dando-lhe uma nova interpretação à luz de documentos inéditos ou conhecidos; não foi o de analisar, com ânimo sereno de historiador, a personalidade do homem e os episódios mais importantes da carreira do político; não foi, por derradeiro, o de escrever, com rigorosa imparcialidade, uma biografia.

A biografia é uma apreciação justa, conscienciosa e verdadeira da vida e da obra de um vulto da história ${ }^{2}$. Ela requer investigação séria, consulta paciente às fontes e ponderação de juízo crítico. Quando o escritor se afasta dêste método, quando manifesta clara e peremptòriamente o desejo de denegrir o biografado, troçando-o, abocanhan-

- livro. Malgrado estas poucas palavras de explicação para o escândalo que suscitou, a verdade é que o escritor nem de longe supôs que haveria de receber a mais formal e enérgica repulsa da consciência literária brasileira. Já lhe deram completa e irretorquível resposta: Salomão Jorge, Um Piolho na Asa da Águia, Ed. Saraiva, 1965; Oswaldo Orico, Rui - O Homem, o Mito e o Mico, 1965. segs.

2. Cf. Luiz Viana Filho, A Verdade na Biografia, pág. 42 e 
do-o e zombando dêle, não pinta um retrato senão uma caricatura, garatujada com linhas deformantes, esgares hediondos e trejeitos abomináveis.

Magalhães Júnior, animado do propósito de escarnecer o biografado com os desprezilhos do ridículo, não podia alimentar a veleidade de escrever para a alta intelectualidade, porque esta, no trato diuturno com RuI, tinha convicção firme a respeito de sua vida e de sua obra, que o farfalhar dos sofismas não podia abalar. Quis dirigir-se, pois, aos incautos e menos avisados, na esperança de lhes perturbar os espíritos, induzindo-os em fácil engano. Ainda aqui malogrou em seu intento, porque nem de leve conseguiu sacudir o prestígio pessoal de Ruı, o valor de sua obra e o seu legado político.

3. Magalhães Júnior analisa, no penúltimo capitulo do livro ${ }^{3}$, tôda a atividade do biografado desde a campanha abolicionista até a conferência de 1919 proferida no Teatro Lírico, abrangendo um largo período de quarenta anos. A preocupação do escritor não é, na verdade, a de desfazer um mito, mas sim a de abater um homem, a quem nega qualquer merecimento em todos os atos da vida; e ainda quando o distingue com algum pobre adjetivo, é para logo feri-lo com doestos, nada lhe creditando, em fôlha, por serviços prestados à Pátria.

Em tôdas as campanhas fundamentais, a que dedicou o melhor de sua existência, Rui teria falhado totalmente. Esste é o asserto categórico do escritor. No movimento abolicionista teve um papel de doutrinador romântico, sem a ampla visão de um André Rebouças, que se inquietou principalmente com o futuro dos escravos, aos quais o Estado devia estender a proteção, a fim de não ficarem expostos à especulação dos fazendeiros ${ }^{4}$. De 1900 a 1910

3. Magalhães Júnior, Rui - O Homem e o Mito, 2.a ed., pág. 349 e segs.

4. Magalhães JúnioR, op. cit., pág. 420. 
ĩromperam no país várias greves, promovidas por operários ou organizações de trabalhadores, que reivindicavam salário mínimo, fixação máxima de horas de trabalho e proteção ao trabalho das mulheres e das crianças. Rur se mostrou insensível a essas lutas justas e imperiosas contra um patronato cruel e impassível ${ }^{5}$. Falhou, pois, como intérprete das aspirações populares dos trabalhadores. Na campanha civilista deu de ombros ao operariado brasileiro, só cuidando da condição dos imigrantes, cujos braços entravam em competição com o do trabalhador nacional ${ }^{\circ}$. E, finalmente, em 1919, quando tratou da questão social, manifestando algum progresso no domínio das idéias, chegou tarde, muito tarde?.

Tudo isso evidencia que Rur nunca acertou. Na questão da escravatura, foi incompleto; na questão social, omitiu-se quando já em 1910 a devia ter encarado corajosamente; e, por fim, ficou desatualizado em 1919, ao acenar soluções, que, no entender de Magalhães Júnior, o operariado já antecipara de muito na reivindicação de seus direitos ${ }^{8}$.

4. Expostas as afirmativas principais que constam dêsse capítulo, já podemos agora descer ao estudo de cada uma em particular, seguindo-lhes o desenvolvimento que têm no livro e analisando-as com rigor, propriedade e seriedade científica. Ver-se-á então que, na primeira das teses, o escritor trucou de falso; na segunda, atribuiu uma omissão não verdadeira; na terceira irrogou uma imputação aleivosa; na quarta, extravasou a indignação, porque RuI como reformista ${ }^{9}$ se filiou à democracia social quando outras perspectivas já eram abertas ao operariado!...

5. Magalhães JúNIoR, op. cit., pág. 425.

6. MAGAlHães JÚNIOR, op. cit., pág. 424.

7. Magalhães JúNIOR, op. cit., pág. 447.

8. Magalhães JÚNIOR, op. cit., pág. 447.

9. Magalhães Júnior, op. cit., pág. 447. 


\section{II}

\section{Da Campanha Abolicionista.}

SUMÁRIO: 5. O doutrinador romântico. 6. A contribuição de RuI para o movimento abolicionista. 7. As idéias do projeto e do parecer das comissões reunidas de orçamento e justiça civil. 8. A instituição do salário mínimo.

5. Começa Magalhães Júnior por dizer que "um dos momentos mais altos da vida de Ruı é a sua participação na campanha abolicionista, ao lado do senador Manuel Pinto de Sousa Dantas ${ }^{10 "}$. Lendo êste período, tem o observador a impressão de que, pelo menos na campanha abolicionista, Rui fêz algo de meritório. Mas o favor daquela frase perde tôda a sua importância, logo que o escritor entra a estudar mais a fundo a contribuição de RuI na emancipação dos escravos. Para Magalhães Júnior, Rui "lutava pela abolição pura e simples "11", o que vale dizer "abolicionismo lírico e romântico", que daria "aos escravos uma liberdade mais teórica que real, tirando-lhes o teto das senzalas em troca de ilusórias cartas de alforria... Ao contrário de tais abolicionistas, apenas um negro de excepcional talento, visão ampla e altas qualidades morais, o engenheiro André Rebouças, sempre se mostrou preocupado na época com outros aspectos do problema, empenhando-se vivamente em promover medidas em favor dos ex-escravos ou estabelecê-los em colônias agrícolas, de modo que não caíssem em nova e pior escravidão. Para os abolicionistas do tipo de Rui era já uma grande conquista completar, sem indenização aos senhores de escravos, a obra iniciada em 1871 com a lei do ventre livre"12.

10. Magalhães JúnioR, $o p$. cit., pág. 420.

11. MagalHães JúNioR, op. cit., pág. 420 .

12. Magalhäes JúNIOR, op. cit., pág. 421. 
A campanha abolicionista de RuI não teve assim maior significado, porque era lírica e romântica, contrastando com a visão ampla e social de André Rebouças. Rur malogrou, portanto, nessa fase inicial de sua vida política.

6. A verdadeira contribuição de Ruı para a campanha abolicionista não consistiu, porém, apenas em proferir conferências inspiradas no ideal generoso e humano de libertar dos grilhões a raça oprimida. Se todo seu quinhão, a bem do movimento, se resumisse num punhado de discursos líricos, ainda assim ninguém lhe poderia negar o mérito de haver patrocinado, com nobreza e desassombro, a mais bela das causas de seu tempo. Era RuI ainda acadêmico de direito, quando estreou na tribuna popular, "encetando-a com a primeira conferência abolicionista que se ousou em São Paulo" ${ }_{13} \mathrm{E}$ depois disso não mais calou a voz até que se apagasse totalmente o estigma que maculou a nacionalidade ${ }^{14}$.

Como deputado, foi o autor do projeto $n .^{\circ} 48$ e relator do parecer das comissões reunidas de orçamento e justiça civil. Nesse documento, de quase duas centenas de páginas, que escreveu no angustioso prazo de dezenove dias ${ }^{15}$, revelou a mais larga e profunda compreensão do grave problema, para cuja solução subministrou idéias realistas do mais elevado alcance social.

7. Segundo o projeto $n .^{\circ} 48$, opera-se a emancipação em cinco casos: I. pela idade do escravo; II. pela omissão de matrícula; III. pelo fundo de emancipação; IV. pela transgressão do domicílio legal do escravo; V. e por outras disposições que especifica. Duas preocupações estiveram presentes na consciência do legislador: a) dar trabalho

13. Rut Barbosa, Obras Completas, vol. XLVI, tomo I, pág. 73.

14. Rui Barbosa, Discursos e Conferências, Pôrto, 1907, pág. 59 e segs.; pág. 117 e segs.; pág. 191 e segs.; pág. 251 e segs.; pág. 271 e segs.

15. Rui Barbosa, Obras Completas, vol. XI, tomo I, pág. 55. 
livre ao ex-escravo; b) recusar ao liberto, em qualquer tempo, a vagabundagem ${ }^{16}$. Prevê o artigo 14: "O Govêrno estabelecerá colônias agrícolas para os libertos que não se puderem empregar em estabelecimentos e casas particulares". E o artigo 15: "Nos regulamentos das colônias de libertos se estabelecerão regras para a conversão gradual do foreiro ou rendeiro do Estado em proprietário de lotes de terra que utilizar a título de arrendamento" ${ }^{17}$.

Aí estava o primeiro importante passo para assegurar aos libertos a condição de subsistência e o germe de uma reforma agrária, dando terras de cultura aos que quisessem semeá-las. Os contratos iniciais de arrendamento evoluíam progressivamente até se converterem em doação de tratos de terra.

Completando estas disposições legais, estatuía o artigo $2 .^{\circ}$, parágrafo $3 .^{\circ}$ do projeto: "O liberto que não exercer profissão ou emprêgo ou não tiver de sua propriedade lavoura ou indústria por onde grangeie a subsistência, será obrigado, pela forma prescrita no parágrafo antecedente, a contratar-se no serviço doméstico, agrícola ou industrial, em casas, estabelecimentos ou obras públicas ou particulares. Parágrafo $1 .^{\circ}$. Reincidindo mais de duas vêzes, além das penas do $\S 20^{\circ}$, incorrerá na de trabalhar de dois a quatro meses, sob a vigilância especial da polícia, em obra do município, província ou Estado, a arbítrio da autoridade policial" ${ }^{18}$.

Reconhecendo que o trabalho livre é uma necessidade, vedava o projeto aos ex-escravos a licença à vagaburdagem.

8. O projeto n. $^{\circ} 48$ enfrenta corajosamente outro problema da mais alta gravidade: o salário minimo aos

16. Rui Barbosa, Obras Completas, vol. XI, tômo I. pág. 194.

17. Rui Barbosa, Obras Completas, vol. XI, tômo I, pág. 246.

18. Rui Barbosa, Obras Completas, vol. XI, tômo I, pág. 243. 
libertos. Prevendo a crítica de que a fixação de salário não se coaduna com a política liberal, Rui diz, no parecer, que "a liberdade e o direito de propriedade conjuntamente opõem-se a tôda fixação oficial de preços no aluguel do trabalho. Ao Estado não assiste jus de interferência alguma na taxação de salários, questão absolutamente particular entre o operário e o patrão"19. Mas logo responde à objeção, contrapondo-lhe que a abstenção do Estado se justifica, "excepto quando se trata de classes inteiras, espoliadas e condenadas, por uma usurpação imemorial, à incapacidade da miséria ou da escravidão civil" $" 20$.

Lançando estas idéias em 1884, quando as legislações dos povos civilizados ainda atribuíam valor quase místico à autonomia da vontade individual na formação do contrato de trabalho, Rui se coloca, històricamente, no Brasil, como pioneiro do moderno direito social: ${ }^{21} \mathrm{e}$ antevendo a luta de classes, que poderia surgir entre patrões $\mathrm{e}$ obreiros num regime de trabalho livre, Rur preconiza a intervenção do Estado, a fim de compôr o conflito de interêsses segundo elevado critério de justiça social. A sua contribuição na campanha abolicionista não foi, portanto, lírica e romântica senão objetiva e realista, com visão clara do problema social, para cuja solução propôs remédios legítimos e profundamente humanos.

19. RUI Barbosa, Obras Completas, vol. XI, tômo I, pág. 199 e seg.

20. Rui Barbosa, Obras Completas, vol. XI, tômo I, pág. 200.

21. SAVATIER, Les Métamorphoses Économiques et Sociales du Droit Civil d'Aujourd'hui, 3. a ed., Dalloz, 1964, pág. 24: "Le droit social, c'est d'abord l'aménagement, dans une civilisation du travail, d'un contrat que le Code Civil avait cru patrimonial, qu'il avait conçu comme individuel et qu'il avait imaginé libre: la convention de louage de services. Et, dans cet aménagement, le droit social acquiert conscience de ce que notre société tout entière est construite sur le travail humain." 
III

Da Omissão de Rui no Período de 1900 a 1910.

SUUMÁrio: 9. Incapacidade de RUI para refletir os anseios das massas. As greves da primeira década do século XX. 10. Surpreendente método de raciocinar. Inexistência de prova da legitimidade das greves. 11. A revisão do Código

Civil. 12. A participação no Congresso de Haia.

9. Prosseguindo na mesma ordem de idéias, sustenta o escritor que Rui, "de espírito eminentemente conservador, não tinha a menor capacidade para refletir os anseios das massas. Perdia-se em considerações meramente políticas, num superficial revisionismo constitucional, cerebrino e desligado da realidade social da época" ${ }^{22}$. Recorda ainda que, na luta contra as pressões a que foram submetidos, deflagraram os trabalhadores greves com freqüência, sem que Rur procurasse inteirar-se dêsses movimentos de legítimas reivindicações de direitos dos operários. Em abôno desta afirmação, historia as seguintes paredes, que se sucederam na primeira década republicana: a) em 1900, a dos estivadores e a dos sapateiros; b) em 1901, a dos pedreiros do Rio e a dos operários de uma fábrica paulista; c) em 1902, a dos tecelões; d) em 1903, a dos cocheiros e carroceiros cariocas; d) em 1905, a dos ferroviários paulistas e a da Companhia de Bondes; e) em 1906, a de Pôrto Alegre, promovida pelos marmoristas, com a adesão de padeiros, tecelões, carpinteiros, pintores, alfaiates, carroceiros e outros; f) e em 1907, a dos pedreiros. E conclui o escritor: "Tudo isso foi obtido à custa de imensos sacrifícios: demissões, prisões, espancamentos e assassinatos de líderes operários pela Polícia. Rur, em tais ocasiões, não abriu a bôca, no Senado Federal, para o mais tímido protesto. É impressionante o seu silêncio e o seu permanente desinterêsse por tais questões" ${ }^{23}$.

22. Magalhães JÚNIOR, Rui - O Homem e o Mito, pág. 425.

23. MAGalhães JÚNIOR, op. cit., pág. 426. 
10. A se crer na aludida descrição, irromperam dez greves pouco mais ou menos nos dois primeiros lustros dêste século: uma no Rio Grande do Sul; as outras, em São Paulo e no Rio de Janeiro. Ora, não tendo Rur proferido no Senado nenhum discurso de protesto contra demissões, prisões e espancamentos, o seu silêncio deve ser havido como desinterêsse por essas questões e incapacidade para refletir os anseios das massas. Eis a conclusão de Magalhães Júnior. É surpreendente, no entanto, seu modo de raciocinar! Do simples silêncio infere que RuI ficara insensivel diante da espoliação dos operários e das arbitrariedades que sofreram. Mas, esquece que, em bôa lógica, lhe corria o dever de provar que Ru tivera conhecimento das greves, seu alcance, legitimidade e repercussão, bem como dos atos de violência praticados pela policia; e não obstante tudo isso, permanecera indiferente a êsses graves sucessos.

Não basta, na verdade, que surja uma greve. É necessário que seja jurìdicamente lícita e moralmente aconselhável ${ }^{24}$, porque a experiência nos mostra que muitas

24. A história da greve é bem conhecida. Em certo logradouro de Paris, onde havia um terreno baldio denominado "Praça da Greve", durante muito tempo se reuniram os operários sem trabalho. Era ali que os empregadores os contratavam. Quando os operários, descontentes com os seus salários, se recusavam a trabalhar, faziam greve, o que vale dizer, voltavam à "Praça da Greve", na esperança de obter melhores propostas (Cf. CROUZEL, Etude Historique, Économique et Juridique sur les Conditions et Les Gréves dans l'Industrie, Paris, 1887, pág. 6; PIC, Traité de Legislation Industrielle, 6. ${ }^{\text {a }}$ ed., pág. 169; M. Cavalcanti de Carvalho, Greve, em "Repertório Enciclopédico de Direito Brasileiro", vol. 24, pág. 22; Sussekind, Maranhão \& SEgadaS VIANNa, Instituições de Direito do Trabalho, vol. II, pág. 502). "Durante muito tempo", escreve PonTes DE MIRANDA, "não se poderia falar de direito de greve. As decisões judiciárias e a mais avançada doutrina juridica negavam e condenavam, em princípio, a greve. Se havia greve, havia violação do contrato de trabalho; portanto, ameaças, desordens, danos, todos ilegais, - ilícitos no plano do direito contratual e, por vêzes, no plano penal. Só se lhe discernia a insurreição social, com a infração do dever ex contractu, pela cessação do trabalho 
delas não passam de obra de agitadores empenhados em promover a subversão social. Sem a demonstração cabal de que Ror se alheara do drama dos trabalhadores, apesar de convencido da necessidade da greve na reivindicação dos seus direitos, a ilação que o escritor tira do silêncio é leviana, ousada e até desonesta.

A malícia de Magalhães Júnior não está apenas nesse modo de raciocinar. Reflete-se principalmente no método de expor. Estudando aquêle período histórico, assinala o que o biografado deixou de fazer a benefício dos trabalhadores, sem realçar, no entanto, o que realizou a favor do Brasil. RuI seria grande aos olhos de seu crítico, se fôsse às portas das fábricas incentivar greves, provocar desordens e preparar a revolução social. Aí, sim, êle revelaria a sua qualidade de líder e intérprete das reivindicações das massas. Mas, como Ruı não tinha vocação de

convencionado." (Pontes DE Miranda, Comentários à Constituição de 1946, 2.a ed., vol. V, pág. 36).

No Brasil, conforme a lição dos doutores, a greve evoluíu de ilícito penal, punido expressamente pelo Código Criminal, a simples recurso meramente anti-social, depois a direito reconhecido por lei ordinária quanto às atividades acessórias e, finalmente, a princípio constitucional que a admite na sua plenitude, regulando-lhe, porém, o exercício no interêsse do bem comum (CESARINo JúnIOR, Direito Social Brasileiro, 3. ${ }^{\text {a }}$ ed., vol. II, n. ${ }^{\circ} 159$; GotTSCHALK, Greve e Lock-out, pág. 70). Na primeira década do século $\mathrm{XX}$, achava-se em vigor o Código Penal, baixado pelo Decreto $n .^{\circ} 847$, de 11 de outubro de 1890. E no capítulo sôbre crimes contra a liberdade do trabalho, foi considerado delito: a) seduzir ou aliciar operários e trabalhadores para deixarem os estabelecimentos em que forem empregados, sob promessa de recompensa ou ameaça de algum mal (art. 205); b) e causar ou provocar cessação do trabalho, para impor aos operários ou patrões aumento ou diminuição de serviço ou salário (art. 206). Mas, como esclarece BAptista PEREIRA, por mal compreendidas, as disposições dos citados artigos levantaram suspeitas na classe operária; o Govêrno Provisório, dois meses depois de publicado o Código Penal, expediu o Decreto $n .^{\circ} 1.162$, de 12 de dezembro de 1890, e alterou-lhes a redação, cessando o clamor, muito embora a solução não contentasse os mais exigentes (BAPTista Pereira, $O$ Código Penal de 1890, em "Revista de Jurisprudência", vol. V. pág. 248). 
agitador comunista, lança-lhe ao rosto a tacha de indiferente aos problemas dos trabalhadores.

11. Nos albores do século XX o Brasil ainda ensaiava os primeiros passos na formação de seu parque industrial. As poucas fábricas existentes no país reuniam diminuto número de operários. Uma parte considerável da imigração estrangeira, destinada ao campo, desbravava matas e abria fazendas; outra, que se radicava nas capitais, queria trabalhar, produzir e vencer. Não havia, na verdade, questão social, porque a terra, nova e rica, oferecia oportunidade para todos que queriam progredir ${ }^{25}$. Os problemas fundamentais dessa fase histórica eram de outra ordem. Os fundadores da República preocupavam-se em consolidar o regime, aperfeiçoar-lhe as instituições politicas, reconhecer solenemente os direitos do homem e preparar a reforma dos principais Códigos, que deviam suceder às obsoletas Ordenações do Reino ainda em vigor no Brasil.

Foi nessa década tão malsinada pelo crítico que Rur prestou um dos mais relevantes serviços à Pátria. Estava na ordem do dia o Projeto de Código Civil elaborado por Bevilacqua. O Senado cometeu a Rur o encargo de proceder à revisão literária, corrigindo-lhe as impropriedades, brunindo-lhe o texto e dando-lhe a última demão para transformá-lo em um monumento legislativo do mais alto valor. Após labor paciente e construtivo, apresentou Rur o seu famoso Parecer, que o Senado houve por bem adotar. Dos méritos desta obra, não há que dizer. O Código Civil, como saira da lavra de Rui, é, sem favor, a lei mais perfeita já escrita no Brasil pelo rigor de sua técnica, pela elegância de sua linguagem e pela fôrça, esplendor e beleza que imprime ao idioma ${ }^{26}$.

25. Sôbre o progresso do Brasil na primeira década do século XX, ver: GILberto FreYre, Ordem e Progresso, vol. II, pág. 470 e segs.

26. "O que é êste Parecer, escreveu Bevilaqua, "sabem-no todos, pois não só os juristas se interessaram por êle, senão também os literatos e, ainda, os que apenas sabiam ler. Foi uma obra, que causou 
Nasceu daí, porém, uma das mais acerbas polêmicas entre Rui e Carneiro Ribeiro, dando lugar à publicação de duas obras que marcam o ponto culminante das investigações filológicas e gramaticais: a Réplica e a Tréplica ${ }^{27}$. Consumam-se anos nessa árdua fadiga de dotar o país de um Código Civil, digno de sua cultura e de seu progresso.

12. Apenas saira dessa polêmica que provocara tantas irritações e agastamentos, já outro encargo da mais alta significação estava reservado a RuI. Por sugestão do Czar da Rússia deviam reunir-se em Haia, no ano de 1907,

profunda impressão no país. Ao fazer-lhe uns tímidos reparos, dizia eu: "O choque violento dessa mole ingente de saber profundo e rude crítica filológica que, das mãos ciclópicas do senador RUI BARBosA, acaba de ruir, fragorosamente, sôbre o Projeto de Código Civil, deixoume aturdido." (Em Defesa, pág. 373). E êsse foi o estado de espírito do grande número: o assombro admirativo." (BevilacQua, Código Civil, 10. a ed., vol. I, pág. 35).

27. RuI apresentou ao Senado, a 3 de abril de 1902, o seu Parecer. A imprensa oficial o publicou, nesse mesmo ano, num volume de 561 páginas em oitavo grande. Nesse trabalho monumental analisou RUI o Projeto artigo por artigo e propôs as modificações literárias. O método seguido foi o de inserir lado a lado o texto original e a nova redação, de modo que o leitor os visse num relance. Os que foram atingidos pela crítica de RUI sairam logo à luta. Mas, dentre todos os polemistas foi CARNEIRO RIBEIRo incontestàvelmente o mais brilhante, o mais douto e o mais vigoroso. A 25 de setembro de 1902 concluía CARNeIro Ribeiro as Ligeiras Observações sôbre as Emendas do $d r$. Ruy Barbosa feitas à redação do Projeto do Código Civil, publicadas um mês depois no Diário do Congresso, suplemento n. ${ }^{\circ}$ 201, pág. 13 e segs. RuI prepara então a sua Réplica, dando-a por acabada a 31 de dezembro de 1903. A imprensa oficial a tira a lume em 1904. Nesta obra, diz August Magne, Rui, "com pasmosa erudição e irretorquível dialética, rebate as arguições dirigidas ao Parecer." (Augusto Magne, Obras Completas de Rui Barbosa, vol. XXIX, tômo I, prefácio, pág. XIV). CÂndido Figueiredo, na sessão de 6 de março de 1919 da Academia de Ciências de Lisbôa, enaltece a Réplica como "um monumento da linguística e de dialética", acentuando que "ainda não se publicou obra mais profunda e mais prestadia em assuntos de língua portuguesa." (Cf. Revista de Lingua Portuguesa, vol. I, pág. 34). 
as nações do mundo civilizado. Ocupava a êsse tempo o Ministério das Relações Exteriores o Barão do Rio Branco. Dois homens preenchiam os requisitos para representar o Brasil naquele memorável congresso: Rui e Nabuco.

Nabuco, elegante, apolíneo, culto, dominando com raro brilho o francês e o inglês, era um diplomata de carreira bem relacionado e afeito ao trato das questões internacionais. A sua larga experiência lhe assegurava uma posição invejável. Ruı, ao contrário, se ocupara sempre com a política interna, fôra Ministro da Fazenda no Govêrno Provisório e naquele momento representava a Bahia no Senado Federal. A sua participação no Congresso de Haia tinha o sabor de uma experiência nova neste gênero de debates internacionais.

Rio Branco tinha de optar entre o diplomata consagrado e o jurista que iria fazer a estréia. Desgraçadamente não era possível incluir os dois na delegação, porque se Rur devia de ser o primeiro, Nabuco não podia ser o segundo ${ }^{28}$. A escolha recaíu em $\mathrm{RuI}^{29}$, que aceitou o convite e partiu para Haia. Para qualquer outro, tal improvisação podia parecer uma temeridade. Mas para Rui assumiu o caráter de trabalho sério, devotado e consciencioso. Madruga às cinco, estuda tôdas as matérias da agenda, orienta os companheiros de delegação e redige os discursos.

28. Nabuco, em carta dirigida a Graça Aranha, justifica: "Por mais que eu deseje dar ao Rui essa prova de amizade e confiança, por mais que me custe não estar com êle na Europa..., não posso ir a Haia como segundo e êle só poderá ir como primeiro... Nenhuma nação mandou a Haia na primeira conferência um embaixador como segundo delegado..." (Cf. Luiz Viana Filho, Rui \& Nabuco, pág. 72).

29. Luiz Viana Filho, $A$ Vida de Rui Barbosa, Editôra Nacional, 1949: "Não tendo podido enviar Nabuco, tão afeito aos torneios diplomáticos, pediu que fôsse à Europa dizer aos seus amigos da “carrière" quem era Rui. Prepararia a platéia para receber o grande artista. Ao contrário do que se poderia supor, Nabuco não guardou qualquer mágua por lhe ter Rui arrebatado involuntàriamente a honraria. E muito cioso da correção das suas atitudes, dedicou-se com abnegação à tarefa." 
Está a braços com o tempo, não perdendo um minuto.

De sua atuação naquele torneio internacional, não há necessidade de fazer-se o louvor. Aquêle que entrou como desconhecido no Congresso, dêle saíu com o cognome de "Águia de Haia" 30. Foi a justiça que lhe fêz a história, laureando-lhe o esforço, a inteligência e a defesa dos bons princípios. Assim, na primeira década republicana dêste século, completa Rui a sua obra de legislador no plano interno e no plano internacional. Nada disto, no entanto, impressiona Magalhães Júnior, que preferia vê-lo, não no Senado, revendo o Código Civil, nem em Haia, legislando para o universo, mas defendendo umas poucas greves sem qualquer significação, surgidas esporàdicamente antes que houvesse no Brasil a chamada questão social.

\title{
IV
}

\section{Da Campanha Civilista.}

\begin{abstract}
SUMÁRI0: 13. O Brasil ensaia a sua primeira grande experiência democrática. 14. Três censuras a RUI na campanha civilista. 15. RuI não ignorou o problema da regulamentação do trabalho. 16. RuI tratou do problema já em 1884. 17. Inexistência da "questão social" Cotejo entre Rvi e o Marechal Hermes da Fonseca. 18. Tratamento igual para brasileiros e estrangeiros quanto aos direitos civis. 19. Justięa chã e quase gratúita não é tribunal de exceção para imigrante, mas fôro comum de todo trabalhador rural.
\end{abstract}

13. A campanha civilista!... O Brasil ensaia a sua primeira grande experiência democrática, despertando do torpor em que o meteram os políticos habituados a esco-

30. Luiz Viana Filho, A Vida de Rui Barbosa, pág. 331 e segs.; Clodomir Cardoso, Rui Barbosa, Rio, 1926, pág. 275 e segs.; João MaNgabeira, Rui - O Estadista da República, Ed. José Olímpio, 1943, pág. 110 e segs.; Mario DE LIMA Barbosa, Rui Barbosa na Política e na História, pág. 199 e segs. 
lher os Presidentes da República nos conchavos dos partidos. Rur é candidato à suprema magistratura da nação. Rư e só RuI, pelo desassombro de suas atitudes e pela eloqüência de sua palavra inspirada, é capaz de sacudir o país ${ }^{31}$. Ele fala ao povo, dando-lhe a consciência do valor do voto. A mocidade freme de entusiasmo, num idealismo mais intuitivo que racional, vendo em RuI o homem da resistência ao poder, o defensor intemerato das liberdades civis e o evangelista da democracia. As massas, convictas de que RuI era o sumo intérprete dos anseios populares, aplaudem-no delirantemente nas ruas, nas praças e nos teatros. Não indagam se a vitória, alcançada nas urnas, seria esbulhada na apuração final pelo Congresso $^{32}$. 0 importante era romper com os corrilhos de bastidores e inaugurar uma política de consulta à

31. JoÃo MANGABEIRA descreve as apreensões do partido oficial, quando é lançada a candidatura de RUI à Presidência da República, recordando um interessante diálogo travado entre Rafael Pinheiro e Pinheiro Machado: “À noite de 20 estava eu no Café Lamas, quando entrou Rafael Pinheiro, partidário exaltado da candidatura Hermes e meu amigo de infância. $\mathbf{E}$ contou-me que, à semelhança de quase todo mundo, julgava que o candidato mais temível que o marechal podia ter era Rodrigues Alves e o mais fraco RUI BARBoSA, que não tinha por si nenhum partido, mas, em compensação, tinha pelas suas idéias e lutas muitos inimigos. Assim, mal soube que Rodrigues Alves recusara definitivamente a candidatura e que 0 candidato civil era Rur, voou ao Môrro da Graça para dar a notícia ao Pinheiro. E êle a deu nestes têrmos mais ou menos: "General, não podíamos ter melhor candidato contra nós. O Rodrigues Alves recusou, e o candidato é o Rui." "Vi que todos concordaram comigo", mas Pinheiro, levantando-se respondeu: "Vocês se enganam. Não podíamos ter pior candidato. Eu queria aquêle conselheiro da Monarquia. Porque ficava tranquilo na sua casa e a campanha não passaria de dois ou três discursos dos seus partidários no Congresso. Fechadas as Câmaras, tudo acabado. Mas com RuI têmo-la travada. Vai agitar êste pais na imprensa e em tôdas as tribunas. Não tem mêdo de nada. Há uma coisa, meninos, que o Rur tem mais do que talento: é coragem. Vocês não conhecem o RUI $e$ eu conheço." (JoÃo MANGABEIRA, Rui o Estadista da Repríblica, pág. 136).

32. Pedro Calmon, História do Brasil, vol. V, pág. 259. 
vontade popular, de claridade nos debates e de nítidas afirmações de princípios. $E$ tudo isso foi conseguido no movimento civilista por um homem que, no calor da pregação, teve a virtude de transmitir ao povo uma mensagem de pensamento, de verdade e de fé.

14. Ao apreciar êsse episódio, que tão funda influência exerceu na história das idéias democráticas no Brasil, Magalhães Júnior não vê o que há nêle de fecundo e construtivo, o seu significado no plano da reforma constitucional, o merecimento de haver lançado as bases de uma nova política objetiva. Nada disso interessa ao crítico, que lê com desdem os famosos discursos de propaganda eleitoral e a plataforma do candidato civil à Presidência da República. Só lhe preocupa a questão social, a cujo respeito escreve que RuI revelou não ter "a menor capacidade para refletir os anseios das massas. Perdia-se em considerações meramente políticas, num superficial revisionismo constitucional, cerebrino e desligado da realidade social" 33 .

"Candidato à Presidência da República, em 1910, com o apoio oficial de São Paulo", prossegue o escritor, "êle (RuI) ignora inteiramente o problema da regulamentação do trabalho e não fêz, em sua plataforma, qualquer referência ao operariado. Menos ainda em garantias a lhe serem asseguradas. Só pensa, então, em proteger os imigrantes, os braços importados para concorrer com o trabalhador nacional, tanto quanto êste digno de amparo, não, porém, de forma exclusiva. A longa plataforma, no que toca ao trabalho, cuida apenas de sugerir meios de regular as relações entre fazendeiros e os colonos trazidos da Europa. Principalmente através da ação de uma justiça chã e quase gratuita, à mão de cada colono, com um regime imburlável, improtelável, inchicanável. Quanto ao trabalhador brasileiro, nada" ${ }^{34}$.

33. MAGALHÃES JÚNIOR, op. cit., pág. 425.

34. Magalhães JúNIOR, op. cit., pág. 424. 
Das passagens que acabam de ser transcritas ressaem contra Ruı três juízos principais: a) ignorou inteiramente o problema da regulamentação do trabalho; b) deixou de tratar da "questão social"; c) e preocupou-se em amparar - imigrante estrangeiro, sem oferecer ao trabalhador brasileiro garantias similares. Mas estas críticas irrogadas a Ruı não são apenas injustas, senão também injuriosas.

15. Na primeira assacadilha, diz Magalhães Júnior que RuI "ignorou" o problema da regulamentação do trabalho. Ignorar é, no sentir dos mais autorizados lexicógrafos, não saber, desconhecer ${ }^{35}$. Empregando aquêle verbo na única acepção que lhe registram os dicionários, Magalhães Júnior exproba-lhe grave lacuna na formação jurídica e condenável omissão na atividade política, desdenhando a classe de operários. Mas a imputação é clara e manifestamente aleivosa.

Rui dominava sobranceiramente tôda a ciência juríđica. Ninguém rivalizava com êle na extensão do conhecimento, na profundidade das pesquisas e no esplendor da erudição. Ao tratar de qualquer assunto, seja de direito público, seja de direito privado, pontificava como se fôsse um especialista que se dedicou, durante tôda a vida, ao seu estudo e meditação. A história das instituições e o direito comparado the eram tão familiares que discursava sôbre ambos com a mesma segurança com que interpretava o direito nacional ${ }^{36}$. Os trabalhos que lhe saiam da

35. Assim Bluteau, Vocabulário Português e Latino, vol. IV, pág. 43; Fr. Domingos Vikira, Tesouro da Língua Partuguesa, vol. III, pág. 1.010; Moraes, Dicionário da Língua Portuguesa, vol. II, pág. 128; Candido de Figueiredo, Nôvo Dicionário da Lingua Portuguesa, $4^{\mathrm{a}}$ ed., vol. I, pág. 1.043; CALdAS AULETE, Dicionário Contemporâneo da Lingua Portuguesa, vol. II, pág. 57.

36. Haja vista RUI BARBosa, $O$ Direito do Amazonas ao Acre Septentrional, 2 volumes, Rio, 1910; As Cessões de Clientela e a Interdição de Concorrência nas Alienações de Estabelecimentos Comerciais e Industriais, Rio, 1913. Os Actos Inconstitucionais do Congresso e do 
pena avultavam pelo saber, clareza e originalidade, exaurindo a matéria em densas monografias ou anunciando profèticamente soluções de validade universal. Dotado de espírito científico e cultura enciclopédica, Rur desamava a improvisação que nunca praticou.

16. Pois bem. Uma das primeiras vozes que se levantaram no Brasil para justificar a intervenção do Estado no domínio das relações econômicas foi a de RuI, quando, em 1884, escrevendo o Parecer ao Projeto n. 48 A, proclamou: "A liberdade dos contratos está, em tôda parte, subordinada a restrições, que se fundam na decência e na dignidade humana" ${ }^{37}$. Não cuidou Rur de enunciar apenas uma fórmula geral de composição de conflitos de interêsses individuais; descendo ao exame dêsse problema, nomeadamente no direito agrário, lembrou em outro lugar as excelências do sistema inglês adotado pela lei de 1881 . "Dessas exceções, impostas às pretensões do direito absoluto pela relatividade dos fatos e pelos interêsses superiores da humanidade", ressaltou RuI, "oferece-nos um caso solene a legislação contemporânea da Inglaterra. A lei agrária de 1881, além de estabelecer, a favor do rendeiro, um condomínio perfeito com o senhor hereditário da terra, criou uma instituição, que amplamente cerceia a liberdade, até então plena, de ajuste entre o arrendatário e o proprietário sôbre o preço do arrendamento. Em todo o arrendamento anual, sujeito a essa lei, é permitido ao rendeiro (tenant), ou, de mútuo acôrdo, ao rendeiro e ao landlord, ou ao landlord de per si só, dirigir-se à comissão agrária (Land Commission) e suas subcomissões, para lhe fixarem o justo valor do aluguel da terra (fair rent). 0

Executivo ante a Justiça Federal, Capital Federal, 1893; Posse de Direitos Pessoais, em "Coletânea Jurídica", Comp. Ed. Nac., 1828, pág. 354 e segs.; Finanças e. Política da República, Capital Federal, 1892;

37. Rui Barbosa, Obras Completas, vol. I, tômo I, pág. 207. 
tribunal ouvirá as partes, atendendo aos interêsses respectivos de cada uma, ponderará tôdas as condições do pacto, da renda e do distrito onde estiver a propriedade arrendada. Êstes juízes são investidos de uma autoridade discricionária. "Incumbidos de determinar a taxa da renda, têm nas suas mãos a sorte de todos os interêsses, que dizem relação à posse e cultivo do solo irlandês. Nas causas que se lhes submetem, a lei não sujeita os comissários a nenhuma prescrição de direito escrito: confia à sua prudência o encargo de solver as questões complexas, que lhes comete deslindar, recomendando-lhes simplesmente que não se guiem senão pelo interêsse da justiça. É, por excelência, uma justiça de eqüidade". (FourniER, Question Agraire en Irlande, pág. 184. Ver também FreDERICK Pollock, The Land Law (Londres, 1883), pág. 133 e seg.). A renda fixada pelo Irish Land Comission denomina-se renda judiciária (judicial rent), será pagável desde a data do primeiro vencimento subseqüente à decisão do tribunal (An act to further amend, art. $8 .^{\circ}, \S 2 .^{\circ}$ ), e vigorará por quinze anos (ib art. $\left.8 .^{\circ}, \S 7 .^{\circ}\right)$. Não é certo, pois, que o princípio da liberdade dos contratos recebeu com o Land Act de Gladstone um profundíssimo golpe? "O parlamento", diz o autor de um notável estudo sôbre essa reforma, "teve de sacrificar o princípio da liberdade dos contratos; princípio cuja aplicação a Irlanda não poderia suportar". (FourNiER, op. cit., pág. 184). Nesse princípio, todavia, estribavam os apologistas da grande propriedade e os interêsses da oligarquia agrária dos lordes a sua oposição ao ministério liberal. Invocando as leis da economia política, reclamavam que se deixasse ilesa a liberdade das convenções particulares, direito inviolável, cuja supressão ofenderia igualmente na sua personalidade o proprietário e o rendeiro. A essa coarctada respondia simples, mas vitoriosamente, a Land League que os grandes mestres da ciência pressupõem a igualdade entre as partes contratantes como base da liberdade dos 
contratos, e que esta, pois, absolutamente não pode existur, na sua verdadeira acepção, desde que essa igualdade não exista (James Howard, M. P. The English Law Question: past and present (Birmingan, 1881), pág. 18). Quem desconhecerá a importância do fato que acabamos de apontar, relativamente às noções consagradas até hoje quanto ao direito de propriedade territorial e suas conseqüências?" 38

Quando em 1884 escreve Rur essa página admirável, aplaudindo o movimento de renovação de idéias tendentes a humanizar as relações entre o capital e o trabalho; quando louva a reforma agrária através de uma legislação que ampara o rendeiro em face do senhor da terra; e quando justifica a intervenção do Estado no domínio dos contratos, a fim de evitar que a liberdade sacrifique a dignidade da criatura, - as suas palavras adquirem caráter quase messiânico, sobretudo porque constituem uma reação à escola liberal, que ainda domina a economia no derradeiro quartel do século $\mathrm{XIX}^{39}$. Ėstes vaticínios, que anunciam a aurora de novos tempos, foram feitos antes mesmo que Magalhães Júnior tivesse sequer nascido. E Rui era um ignorante!!!

38. Rui Barbosa, Obras Completas, vol. XI, tômo I, pág. 200 e segs.

39. René Gonnard, História das Doutrinas Econômicas, Lisbôa, vol. II, pág. 318: "Crença firme nas leis econômicas naturais, confiança no fator individual, no interêsse particular e na responsabilidade pessoal, inabalável apêgo aos princípios de liberdade e propriedade, cosmopolitismo, desdém da história, condenação do estadismo econômico em tôdas as suas manifestações, método geralmente abstrato e dedutivo, tendência crematística e amoral, tais são os traços mais gerais e mais constantes que se notam nos economistas desta escola na primeira metade do século XIX e, mais adiante, embora se possam alguns diminuir, e até por vêzes faltar neste ou naquele." Ver ainda: JEAN Chevaliar, Doctrines Economiques, Paris, 1947, pág. 119 e segs.; Kretchmann, Storia delle. Dottrine Economiche, Torino, 1949, pág. 92 e segs.; GaStaldi, Elementos de Economia Política, pág. 32 e segs. 
17. A segunda increpação é de que Rui não tratou da questão social na plataforma de candidato à Presidência da República. Magalhães Júnior coteja a omissão de Rur com o pronunciamento do Marechal Hermes que figura em sua plataforma lida no Teatro Municipal a 26 de dezembro de 1909. E conclui: "Perto da omissão de Rú, Hermes chega a ser ousado, até parecendo ser êle e não o seu adversário o candidato da oposição" ${ }^{40}$. O leitor menos avisado fica inquieto por saber o que de ousado teria dito o Marechal Hermes. Ora, a manifestação dêste, na referida plataforma, conforme citação feita por Magalhães Júnior, é a seguinte: “Não nos assoberbam, ainda, felizmente, os grandes abalos produzidos na luta entre c braço e o capital. O movimento socialista, que tanto apavora as nações do Velho Mundo, onde o progresso industrial $e$ as descobertas científicas vão eliminando, por vêzes, o concurso do operário e onde a escassez do solo lhe não fornece campo para o trabalho remunerado não nos bateu às portas e seria aqui planta exótica, a estiolarse à mingua de elementos de vida. Entretanto, o aumento, sempre crescente, da população, especialmente nesta Capital, a deficiente compensação da atividade e a carestia dos gêneros de primeira necessidade, têm criado uma vida de privações e sofrimentos para os desfavorecidos da fortuna. Daí o problema operário, de difícil solução, pela multiplicidade das faces por que deve ser encarado. Colaboradora do bem geral, a classe dos proletários merece benévola atenção do poder público, sem preterição dos interêsses industriais $e$ do capital que thes proporciona trabalho" ${ }^{41}$.

Assim falou o Marechal Hermes na plataforma em que deu a conhecer as suas idéias como candidato à Pre-

40. Magalhães JÚNIOR, op. cit., pág. 427.

41. MAGALHÃES JÚNIOR, op. cit., pág. 427. 
sidência da República pelo partido oficial. O seu depoimento testemunha a inexistência entre nós da "questão social" e lança formal repúdio ao socialismo, designado como "planta exótica". Mas, para fins eleitorais, lembra os infortúnios que padecem os "desfavorecidos da fortuna", em pról dos quais deita um olhar piedoso. Rur compreendeu o alcance daquela "benévola atenção do poder público" à classe operária e verberou contra o Marechal aquêles tímidos acenos, por se semelharem antes a promessas enganadoras que à proteção real. "De que serve, por exemplo, falar em remédios à classe operária", objurgou Rui, "sem dar a entrever longes, sequer, da meditação a que se alude, traços, ao menos, das providências, em que se cogita? Eu não conheço deshumanidade mais reprovável que a de insinuar no coração dos necessitados esperanças falazes. Os programas são roteiros do amanhã. Não se teem o direito de suscitar neles uma questão grave, sem haver conhecido com alguma clareza o caminho da incógnita, que a deve resolver" ${ }^{42}$.

Rui não tratou, pois, da questão social na campanha civilista, porque ela, em verdade, ainda não havia surgido no Brasil.

18. A terceira diatribe acoima a Rur a preocupação de proteger o colono trazido da Europa, compondo-lhe as relações jurídicas com o fazendeiro através de uma justiça chã e quase gratuita, sem estender, contudo, tal tratamento ao operário nacional. Magalhães Júnior, com esta acusação, pretende infundir no espírito do leitor a idéia de que Rur encarou com descaso o trabalhador brasileiro. Mas esta exegese, além de tendenciosa, é uma deformação

42. RUI Barbosa, Excursão Eleitoral aos Estados da Bahia $e$ Minas Gerais, pág. 166. 
do pensamento de Ruı expresso não só em várias obras, como especialmente em sua plataforma política.

Ninguém ignora que a Constituição do Império só garantia aos brasileiros a inviolabilidade dos direitos civis e políticos (art. 179, pr.). Mas um dos méritos da Constituição de 1891 foi o de igualar a condição dos estrangeiros residentes no país à dos brasileiros quanto à inviolabilidade dos direitos concernentes à liberdade, à segurança individual e à propriedade (art. 72, pr.). "De sorte que", comenta Rưr, "por esta disposição, cuja amplitude não encontra símile nem entre as Constituições européias nem mesmo na dos Estados Unidos, a garantia dos direitos individuais, que, na carta imperial de 1824, era privativa aos cidadãos brasileiros, é, pela Constituição republicana em vigor, fôro comum, assim dos nacionais, como dos estrangeiros residentes no país" ${ }^{43}$.

Rui, que tão solenemente proclamou as vantagens da Constituição republicana justamente no ponto em que equiparou os estrangeiros aos nacionais, jamais haveria de propor um regime de diversidade de tratamento entre êles, beneficiando o imigrante em detrimento do operário brasileiro; porque ninguém, melhor do que êle, sabia que qualquer lei, que consagrasse tal solução, estaria irremediàvelmente eivada de inconstitucionalidade.

19. Por outro lado, não propôs Rui a criação de uma "justiça chã e quase gratuita" exclusivamente para estrangeiros, mas sim para garantir qualquer trabalhador rural. São suas palavras textuais: "À compreensão desta necessidade se devem as medidas tomadas para garantir ao trabalhador rural a certeza do seu salário. A lei n. ${ }^{\circ} 1.150$, de 1904, graduou entre os créditos privilegiados, abaixo

43. Rui Barbosa,Constituição Federal Brasileira, vol. V, pág. 191. 
da hipoteca e do penhor agrícola, os salários dos colonos. A lei n. $^{\circ}$ 1.607, de 1906 sujeitou ao pagamento dêles, com primazia a quaisquer outros créditos, as colheitas pendentes. Pràticamente, porém, estas reformas, bem assim quantas do mesmo gênero se queiram multiplicar, ainda não acertam no ponto vital. Consiste êle na efetividade rigorosa dessas garantias, isto é, criação de uma justiça chã e quase gratuita, d̀ mão de cada colono, com um regime imburlável, improtelável, inchicanável. Tôda a formalística, em pendências entre o colono e o patrão, importa em delonga, em incerteza, em prejuizo, em desalento. Nesta categoria de débitos, não sendo facílima é o mesmo que não ser exequível a cobrança" ${ }^{44}$.

Justiça chã e quase gratuita, à mão do colono, não é um tribunal de exceção instituído para o imigrante, mas fôro comum de todo trabalhador rural. A circunstância de Rui haver tratado dêste tema no capítulo "Da Imigração", tem uma explicação natural e lógica. País que recebia grandes correntes imigratórias, à semelhança da Argentina e dos Estados Unidos, onde o colono estrangeiro contribuíu eficazmente para o seu desenvolvimento e progresso, - o Brasil deveria criar uma organização judiciária que assegurasse ao trabalhador rural o recebimento, sem delongas, de seu salário. A falta de uma jurisdição simples, apta a resolver os conflitos entre colono e patrão, afugenta o imigrante para outras terras, onde espera encontrar as condições mínimas de subsistência. É que "a economia vive da segurança, cuja base é a justiça" ${ }^{45}$.

44. RuI Barbosa, Excursão Eleitoral aos Estados da Bahia e Minas Gerais, pág. 65.

45. RUI BARBosa, Excursão Eleitoral aos Estados da Bahia $e$ de Minas Gerais, pág. 65. 


\section{$\mathrm{V}$}

\section{Da Questão Social.}

SUmÁrio: 20. Duas conferências. 21. Socialismo utópico, científico e cristianismo social. 22. Conceito do direito social. 23. Três princípios fundamentais relativos à questão social. 24. O socialismo do Cardeal Mercier. 25. O programa social preconizado por RuI BARBosa. 26. A síntese Iuminosa.

20. Rư é de nôvo candidato à Presidência da República. A campanha eleitoral fôra curta, mas brilhante. Dentre as conferências então proferidas merecem especial realce o Apêlo às Classes Conservadoras e a Questão Social e Politica no Brasil ${ }^{46}$. A primeira é dirigida aos homens de emprêsa; a segunda, aos operários. Bem que distintas quanto aos assuntos e aos destinatários, elas não se excluem, antes se completam, parecendo os dois lados de um problema único.

Já entrado em anos, prepara Rui, nesses documentos que encerram a segunda década republicana, o seu ideário sôbre a questão social, que a guerra de 1914 exacerbou no mais alto grau. Era chegado o momento de tratar dêste têma pela sua importância, pela sua atualidade e pelas suas graves conseqüências. Ruı o analisa com coragem, lucidez e descortino de estadista.

21. Isto desagrada profundamente Magalhães Júnior, que estigmatiza os dois documentos com doestos, sarcasmos e crítica soez. "O movimento operário", diz "se antecipara a Rui de tal forma que as suas promessas tardias não tinham a repercussão por êle esperada" ${ }^{47}$. E

46. Cf. Rur Barbosa, Campanha Presidencial, 1919, pág. 54 e segs.

47. Magalhães JúNiOR, op. cit., pág. 447. 
embora Rur aplaudisse no socialismo "o que êle tem de são, de benévolo, de confraternal, de pacificador" ${ }^{48}$; embora adotasse o Código de Malines do Cardeal Mercier, que João Mangabeira considera "muito mais avançado do que qualquer das duas encíclicas Rerum Novarum ou Quadragésimo Anno" ${ }^{49}$; e embora proclamasse que a concepção individualista dos direitos humanos cede lugar aos direitos sociais ${ }^{50}$, - já agora, esbraveja Magalhães Júnior contrafeito e agastado, "era tarde. Era muito tarde para a meia conversão do tenaz conservador" 51 .

Magalhães Júnior nega tudo a Rur. Nega-lhe o dever de atualizar o pensamento político, aderindo ao socialismo cristão ${ }^{52}$; nega-lhe a coerência das idéias pregadas num apostolado de meio século ${ }^{53}$; nega-Ihe até, quando assás avançado na idade, direito de ir de automóvel ao Senado, ao Supremo e às livrarias ${ }^{54}$. Que era necessário a Rui, no entanto, para que Magalhães Júnior lhe concedesse os favores da simpatia pessoal? Não o diz Magalhães Júnior de modo explícito, mas as palavras que the caem da pena denotam consciente ou inconscientemente claro intuito. 0 louvor ao socialismo cristão, nos têrmos em que Ruı o

48. Rui Barbosa, Campanha Presidencial, pág. 124.

49. João Mangabeira, Rui - o Estadista da República, pág. 287.

50. Rui Barbosa, Campanha Presidencial, pág. 1.23.

51. Magalhães JÚNIOR, op. cit., pág. 445.

52. Rut Barbosa, Campanha Presidencial, pág. 123: "Estou, senhores, com a democracia social."

53. Magalhães JúNIOR, op. cit., pág. 445, considera a doutrina de RUI como "parolagem inconsequente, de véspera de eleição, sem o lastro das convições sinceras representado pela constância das idéias e pela reiteração dos atos que as traduzissem."

54. MAGALHãeS JunioR, op. cit., pág. 447: "Homem que não saía de casa senão de carro, para ir ao Senado, ao Supremo Tribunal, ao cinema ou às livrarias, só caminhando a pé, raramente, pela Avenida Rio Brarico, rua do Ouvidor e adjacências..." 
enunciou, com ser puramente utópico, significava apenas meia conversão; a conversão total só poderia ser a completa adesão ao socialismo científico elaborado por Carlos Marx. E como Rú não chegou a tanto na evolução de suas idéias políticas, desmereceu qualquer elogio...

22. Conhecidas as tendências de Magalhães Júnior e identificado o motivo real por que, com tanto ardor, investiu contra as duas conferências de Rur, já podemos descer agora ao estudo da questão social. Compreendeu Rur que, para tratar dêste problema, era indispensável reconhecer $a$ priori alguns princípios de filosofia política, fundado nos quais buscaria encontrar-lhe solução. 0 primeiro dêles era o triunfo de uma nova categoria jurídica, denominada direito social. "A concepção individualista dos direitos humanos", escreveu, "tem evolvido ràpidamente, com os tremendos sucessos dêste século, para uma transformação incomensurável nas noções jurídicas do individualismo restringidas agora por uma extensão, cada vez maior, dos direitos sociais. Já se não vê na sociedade um mero agregado, uma justaposição de unidades individuais, acasteladas cada qual no seu direito intratável, mas uma entidade naturalmente orgânica, em que a esfera do indivíduo tem por limites inevitáveis, de todos os lados, a coletividade. O direito vai cedendo à moral, o individuo à associação, o egoismo à solidariedade humana" 55 .

55. Rui Barbosa, Campanha Presidencial, pág. 123. Quase trinta anos depois de RUI, o filósofo alemão GuSTAvo RADBRUCH dizia do direito social: "O direito social é o resultado de uma nova concepção do homem no direito. Transformações do aspecto do homem, expostas ao legislador, determinam como em nenhuma outra hora do pensamento jurídico as transformações históricas do direito: Das soziale Recht ist das Ergebnis einer neuen Auffassung vom Menschen im Recht. Wandlugen des dem Gesetzgeber vorschvebenden Menschenbildes bestimmen wie kaum irgendein anderes Moment des Rechts denkens die 
O segundo princípio construíu na inclusão de normas de direito econômico nas constituições políticas modernas. "As constituições", assinalava RuI, "são conseqüências da irresistível evolução econômica do mundo. Por isso "as constituições não podem continuar a ser utilizadas como instrumentos, com que se privem de seus direitos aquêles mesmos que elas eram destinadas a proteger, e que mais lhe necessitam da proteção". As nossas constituições têm ainda por normas as declarações de direitos consagrados no século dezoito. Suas fórmulas já não correspondem exatamente à consciência jurídica do universo. A inflexibilidade individualista dessas cartas imortais, mas não imutáveis, alguma coisa tem de ceder (quando lhes passa já pelo quadrante o sol do seu terceiro século) ao sôpro de socialização, que agita o mundo" ${ }^{56}$.

$O$ terceiro princípio era a disciplina jurídica das relações entre o capital e o trabalho. Proclamando que o trabalho não é uma mercadoria, valorizou o operário. Mas verificando que o capital é uma necessidade indeclinável, justificou a colaboração das classes sociais. "Não há nada mais desejável", acentuou RuI, "do que a cooperação entre as classes que empregam e as que se empregam. Os patrões não se devem esquecer de que o seu interêsse prende, trava, entroza com o interêsse social, nem perder jamais de vista que não se pode tratar o trabalho como coisa inanimada ${ }^{57}$. Todavia, deixou claro que o capital "não tem direitos contra a humanidade" 58.

23. À luz dessas idéias, não hesitou Ruı em filiar-se à democracia social, tal como a preconizara o Cardeal

epochalen Wandlungen des Rechts." (RADBRUCH, Vorschule der Rechtsphilosophie, Heidelberg, 1948, pág. 96).

56. RuI Barbosa, Campanha Presidencial, pág. 159.

57. Ru Barbosa, Campanha Presidencial, pág. 158.

58. Rut Barbosa, Campanha Presidencial, pág. 121. 
Mercier, “essa democracia ampla, serena, leal e, numa palavra, cristã; a democracia que quer assentar a felicidade da classe obreira não na ruína das outras classes, mas na reparação dos agravos que ela, até agora, tem curtido" 59 . E escandalizando, por certo, muitos que o ouviam, Rui corajosamente afirmou: "Aplaudo, no socialismo, o que êle tem de são, de benévolo, de confraternal, de pacificador, sem querer o socialismo devastador, que, na linguagem do egrégio prelado belga, rebaixa a questão social a uma luta de apetites, e intenta dar-lhe por solução o que não padia deixar de exacerbá-la: o antagonismo das classes. A meu ver, "quando trabalha em distrair com mais equanimidade a riqueza pública, em obstar a que se concentrem nas mãos de poucos somas tão enormes de capitais, que pràticamente acabam por se tornar inutilizáveis e, inversamente, quando se ocupa em desenvolver o bem estar dos deserdados da fortuna, o socialismo tem razão". Mas não tem menos razão, quando, ao mesmo passo que trata de imprimir à distribuição da riqueza normas menos crueis, lança os alicerces dêsse direito operário, onde a liberdade absoluta dos contratos se atenua, quando necessário seja, para amparar a fraqueza dos necessitados contra a ganância dos opulentos, estabelecendo restrições às exigências do capital e submetendo a regras gerais de equidade as estipulações do trabalho" ${ }^{60}$.

Tal era o socialismo que RuI perfilhava. Socialismo cristão, socialismo humano, socialismo inspirado na idéia de justiça. Socialismo que não odeia, não persegue e não mata. Socialismo que ampara os econômicamente fracos, elimina desigualdades contrastantes e compõe conflitos de

59. Rui Barbosa, Campanha Presidencial, pág. 123.

60. Rui Barbosa, Campanha Presidencial, pág. 124. Sôbre a influência das idéias socialistas na geração da primeira república, ver Gilberto Freyre, Ordem e Progresso, vol. II, pág. 713 e segs. 
interêsses não pela lei da fôrça, mas pela fôrça da lei. Socialismo que respeita as liberdades individuais, repudia o partido único e abjura quaisquer formas de ditadura, nomeadamente a ditadura do proletariado, porque esta implanta a violência em lugar da ordem, oprime a criatura humana destruindo-lhe o espírito criador e semeia a violência organizada justamente onde devia promover o congraçamento das classes ${ }^{61}$.

24. Definida a sua posição no plano filosófico-político, fácil se tornou a Rui passar ao exame dos problemas que afligem os operários, conhecidos sob a denominação de questão social ${ }^{62}$. No programa de realizações em benefício dos trabalhadores, o primeiro ponto era a construção de casas para operários. "Até agora" observou Rur, "o abrigo das classes proletárias é, habitualmente, a casa de cômodos ou a triste arapuca de retalhos de zinco, latas de kerozene e caixas de sabão. Em casa de cômodos se

61. Ao longo da primeira metade do século XIX medraram, na Europa, com largo desenvolvimento, as idéias socialistas, das quais duas foram as correntes principais: o socialismo idealista e o socialismo científico (Cf. PIRou, Introduction a l'Étude de l'Économie Politique, 2. ${ }^{2}$ ed., pág. 259 e segs.). Na segunda metade surgiu o socialismo cristão, que melhor se designa cristianismo social, representado pela notável Encíclica Rerum Novarum do Papa Leão XIII. "Entre meados do século XIX e a primeira guerra mundial", escreve NeLl BREUning, prepondera ao socialismo marxista até o ponto de se ter formado uma visão unitária do mundo e de o socialismo se poder equiparar ao marxismo. A partir de então mais e mais se tornou definitiva a cisão do socialismo marxista em duas alas, uma comunista e outra revisionista; a segunda desliga-se cada vez mais não já do materialismo dialético e histórico, mas das doutrinas econômicas de Marx; a gradação conduzente ao socialismo não marxista torna-se incerta e o socialismo não comunista acaba por se encontrar em completa dissolução ideológica. Deixou de existir uma base comum; como símbolo da união resta ùnicamente uma declarada atitude de crítica social contra a economia do capitalismo e a sociedade capitalista." (BRUGGER, Dicionário de Filosofia, São Paulo, Herder, 1962, pág. 493). 
atestam criaturas humanas como sacos em tulha, numa promiscuidade inconcebível, que lembra os quadros do tráfico negreiro" ${ }^{63}$. O movimento em prol da habitação proletária data dos primeiros anos da fundação da República. Mas as medidas legislativas decretadas pelo Congresso Nacional não chegaram sequer à regulamentação.

O segundo ponto era o trabalho de menores, a cujo respeito o Govêrno Provisório, a 23 de janeiro de 1891, expediu decreto, estabelecendo providências quer quanto à idade, quer quanto à duração. E Rú lamenta que aquêle ato legislativo não tivesse sido regulamentado durante trinta anos de regime republicano, causando "terrível hecatombe ânua de inocentes, cuja responsabilidade se averba tôda ao débito de nossa politicalha, de sua crua indiferença, de sua gelida insensibilidade" ${ }^{64}$.

$\mathrm{O}$ terceiro ponto era o amparo à mãe operária. "Em todos os países", afirmou RuI, "se cercam de atenções meticulosas a gravidez e o parto. Entre os povos civilizados a mulher que está para dar e a que acaba de dar à luz são sagradas aos olhos do homem. Êste sentimento nobre, porém, ainda não calou bastante nos costumes de nossa indústria" ${ }^{65}$.

O quarto ponto concerne ao acidente no trabalho agrícola. A Lei de 15 de janeiro de 1919 só considerou o trabalho industrial. "Como explicar", indaga RuI, "singu-

62. Sôbre o conceito de questão social, não há uniformidade de vistas entre os autores. Ver: CEsarino Junior, Direito Social Brasileiro, 5. ${ }^{\mathrm{a}}$ ed., vol. I, n. ${ }^{\circ}$ 43; JoÃo DA GaMA CerqueIra, Sistema de Direito do Trabalho, vol. I, pág. 325 e segs.; Felipe Pitarque, La Cuestion Social, Barcelona, 1949, pág. 13 e segs.; Viveiros de CASTro, $A$ Questão Social, pág. 35 e segs.; Mario Baronci, La Política Sociale della "Rerum Novarum", vol. II, pág. 115 e segs.; MARCEL ClÉMENT, L'Ėconomie Sociale selon Pie XII, Paris, 1933, vol. I, pág. 26 e segs.

63. Rui Barbosa, Campanha Presidencial, pág. 129. 
laridade tão estravagante qual a de, num país essencialmente agrícola e criador, se esquecerem do trabalho da criação e do da lavoura, os dois únicos ramos do trabalho naturalmente nacionais, os dois só em absoluto nacionais, os dois onde assenta a nossa riqueza, tôda a nossa existência mesma e sem os quais a nossa própria indústria não pode subsistir. Nenhum gênero de labor demanda, entre nós, tão séria atenção dos poderes do Estado como êste dos campos" ${ }^{66}$.

25. Rui, contudo, não para aí. Procurando abarcar todos os aspectos da questão social, analisa a duração do trabalho, a higiene na indústria privada e nas oficinas do Estado, as indenizações e o seguro, o trabalho noturno e domiciliar e a prática dos armazens de venda aos operários. $\mathrm{E}$ depois de estudar cada um dêstes problemas em particular, traça o plano de redenção do trabalhador na república, do mesmo modo que fizera em relação ao escravo nos fins do império. $O$ que há de admirável é, porém, a síntese em que condensa todo o vigor de seu pensamento. "Na sorte do operário", declarou, "culminam três problemas capitais: a justiça, a instrução, a nobilitação do trabalho" 67 .

Nesta fórmula, de rara felicidade, exprime Rur a inquietação do homem, a atualidade do pensador e a visão do estadista. O que preconiza para o trabalhador, a fim de resolver a questão social, ${ }^{68}$ é justiça e não caridade:

64. RuI Barbosa, Campanha Presidencial, pág. 132.

65. Rui Barbosa, Campanha Presidencial, pág. 134.

66. Rui Barbosa, Campanha Presidencial, pág. 137 e seg.

67. Rui Barbosa, Campanha Presidencial, pág. 88.

68. Sôbre o pensamento de RUi Barbosa, ver: ERNesto LEme, Rui e a Questão Social, pág. 19 e seos.; CESARINo JunIor, Rui Banjosa e a Questão Social (Anuário da Faculdade de Ciências Econômicas e Administrativas, 1949/1950, pág. 193 e segs.). 
instrução que eleva e não revolta que humilha; dignificação do trabalho e não sua redução a simples mercadoria. Esta é a mensagem de Rur. Transmitida quase ao fim de uma longa existência devotada à Pátria, ela traduz, pela continuidade e coerência de suas idéias, o coroamento de um luminoso apostolado.

As mensagens, que se eternizam, são as que têm validade universal. Rur pensou, falou e escreveu para todos os povos e tôdas as idades, porque o seu ideiário político representa um anseio de tôda a humanidade. 